\title{
Is Germany Self-Sustaining in War?
}

\author{
Ability to Provide Food and War Materials from Domestic Sources a Great Element of Her Strength
}

By Benjamin Baker

$G_{\text {miliary }}$ expraordinary isolation in both the $\mathbf{G}_{\text {military and }}$ commercial relations of the empire has been fully noted in the daily press; and much has been made of the fact that she usually imports about a third of the wheat she uses, and all of certain textile materials, such as raw cotton and silk. It has been confidently predicted that the war will result in the ruination of her foreign trade and the utter prostration of her industries; while it seems to be assumed, without much evidence of any careful study of the situation, that in the matter of food supplies particularly, the war will quickly lead to scanty fare, if not to widespread hardships, from actual lack of food.

But this notion, while it has something to support it, fails to grasp the fact that Germany can support herself on her home resources for fully a year, and that this capacity for self-support in the face of a universal embargo has a very high military value. It is probably true that long before next August, if the war were to last as long as that, the people of Germany would be put to many shifts from their usual mode of living. They might, for instance, have to learn to eat a greater part of their annual production of some two billion bushels of potatoes which are now mostly used in the production of industrial alcohol. In the absence of imports of raw cotton, they would undoubtedly have to economize on stockings, underwear, and shirts. But they could very well do these things, and many others that necessity might require, without any real bodily suffering. The South, in our Civil War, cheerfully endured privations much greater than any of a material sort likely to afflict the German people in the course of a year's war.

Germany is still largely an agricultural country, though the prominence of her manufactured goods in American markets has probably led most of us to think of her as mainly a commercial nation. Nine tenths of her area of 208,000 square miles, inhabited by some seventy million persons, is productive. Her arable lands, including vineyards and other cultivated tracts, total over $65,000,000$ acres, or practically half the entire area of the country. At a pinch she can feed herself for a long time. She is similarly self-sustaining, but more so, in the matter of all military supplies and appliances. Besides the cultivated lands, grass meadows and permanent pastures take up over 21,000,000 acres, while woods and forests occupy 35,000,000 acres. In 1910 over $10,000,000$ persons were engaged in agriculture on a total of five and three quarters millions of separate inclosures or farms. Many of these farms were very small, but the enumeration takes in none under three acres in area. The largest estates are in East and Wes Prussia and in the Prussian provinces of Pomerania, Posen, and Saxony; while small farms are the rule in the Prussian Rhine province, in Baden, and in Wurttembury. It is noteworthy that the agricultural population, living by farming, and living on the farms, is only about a million less than the total number of persons engaged in manufacturing pursuits, including the textile industries-or ten millions for farming agains eleven millions for all manufacturing.

Cereals the Food Problem for Germany.

The statistics of home production and of imports of cereal foodstuffs probably present the German food situation in a somewhat worse light than the facts as to all the food supplies justify. Germany is an exporter of beef in large quantities to both England and Frence, yet in the current discussion of the food issue this fact, and its significance to Germany under the present circumstances, is wholly overlooked.

Germany's home production of foods from the soil last year, 1913 , totaled $84,783,000$. metric tons, the metric ton being the unit for all the official German statistics of production. The metric ton equals 2,204 English pounds, or nearly the "long ton" with whic Americans are familiar. The figures in metric tons can be roughly converted into bushels by multiplying the figures in tons by 37.6. This would give the cerea production of last year, plus potatoes, at about 3,285, 000,000 bushels, or 47 bushels per capita for the entire population of the country. From a dietetic point of view, the proportion of potatoes is of course too high. In detail the crops for 1913 were:

\begin{tabular}{|c|c|c|}
\hline & Metric Tons. & Bushels. \\
\hline & $\begin{array}{r}4,656,000 \\
12,222,000\end{array}$ & $\begin{array}{l}176,000,000 \\
462,000,000\end{array}$ \\
\hline Barle & $3,673,000$ & $139,000,000$ \\
\hline & $\begin{array}{r}9,714,000 \\
5412000\end{array}$ & 366,000,000 \\
\hline
\end{tabular}

Imports of grains in 1913 are given in the Germa official figures by their values in marks; the values can be converted into dollars by dividing the figures in
How long can the German Empire feed its population from domestic products alone? Long before the outbreak of the present war, the question was much discussed not only by Germans, but by French and English writers as well. Dr. Carl Ballod of the University of Berlin took a distinctly pessimistic view of Germany's ability to feed herself in the Preussische Jahrbiicher. His article was a reply to Count von Moltke, who published far more optimistic views in the same periodical. In the article appearing on this page, $\mathrm{Mr}$. Benjamin Baker, after carefully examining statistics, shows that Germany can support herself for fully a year.-EDiror.

marks by 23.8 , that being the value of the mark in ou currency at the par of exchange. A rough method is to divide the figures in marks by four, to get the value in dollars. The imports last year were:

\begin{tabular}{|c|c|}
\hline $\begin{array}{l}\text { Wheat } \ldots . . . \\
\text { Rye } \ldots . . . . \\
\text { Barley } \ldots \\
\text { Indian corn }\end{array}$ & $\begin{array}{r}\text { Marks. } \\
429,000,000 \\
44,000,000 \\
407,000,000 \\
106,000,000\end{array}$ \\
\hline Total & 000,000 \\
\hline
\end{tabular}

As given by the U. S. Department of Agriculture, the cereal imports of Germany were

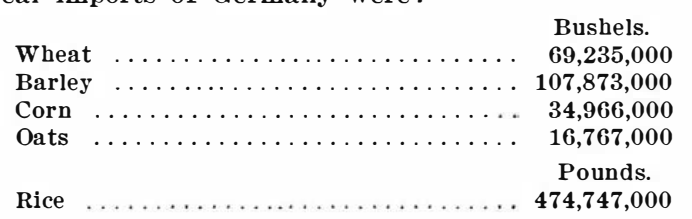

About 7,000;000 bushels of rye were exported in the same period.

The tables of production and of imports of cereals show that Germany now imports about one fourth of the wheat she uses, and naturally all the rice, the imports of rice being somewhat larger than those of wheat. In the period from 1900 to 1905 , both years in cluded, the four cereal crops named in the first table above averaged about $840,000,000$ bushels, and durin the same period the imports of cereals averaged about $170,000,000$ bushels, or nearly one fifth of the home production. Barley is imported largely from Russia, little of this Russian grain being fit for the manufacture of beer. Possibly there may be relief in this direction in a much diminished brewing of beer, releasing the hom supply, or much of it, for a different form of consumption.

Tabulating the production and import of cereals, however, does not wholly clear up the details of the food situation of Germany, because of the fact that, while the total imports of foodstuffs last year amounted to a little over seven billion marks, the cereal import given in the second table above total less than one milion marks, exclusive of rice; and with rice included, the total will hardly rise above the million mark, or one seventh of the total food and agricultural imports. Fish, which has been generously imported, will be largely cut off by the war. The total value of the German fisheries in 1912 was about a billion dollars, and this was supplemented by imports mainly of cod an herring. Most of this came from the North Sea, and its failure will be felt in the large seaports on that coast.

\section{Cattle Industry Makes Exports.} production, furnishing an excess which has supplied a growing volume of exports to both France and England. The retention of the beef formerly exported will of course add considerably to the home food resources of the empire. Cattle raising is mainly carried on in the south and southwest of Germany, the pastures in the foot-hills of the Alps supporting large numbers of animals.

Horse breeding is another animal industry that is carried on with great success both as to numbers and as to quality of animals. The main centers for this industry are in East and West Prussia, which is a great plain region; the marsh districts of the Elbe and Weser, to the northwest, and some parts of Westphalia, Oldenburg, Lippe, Saxony, and Upper Silesia. The stud farms of Trakihnen in East Prussia, and Graditz in the Prussian province of Saxony, have a European reputation.

Sheep have been declining pretty steadily in Germany since 1860 , the number having fallen from $28,000,000$ at the earlier date to some five or six millions now. This represents not only a decrease in home meat production, but also in wool supply, a large part of which now has to be imported for the textile industries.

\section{Plenty of War Material and Plants.}

As to war material of every sort, Germany is entirely self-contained. Her great shipyards and the enormous armor and gun plant of the Krupps are known the world over. She can not only build the machines of war, but she has the raw materials within her own borders. Up to recent years Germany imported Swedish iron for the making of steel by the Bessemer and open hearth processes; but since the Bessemer process has been modified to make use of phosphorusbearing iron ores, Germany has made her steel from the abundant ores of Lorraine and Luxemburg, and has built up a large export trade in bridge and railway material, which she has sold largely to Russia and France. In engines and machines she ranks next to England, and her exports of these cover the world.

The mineral production of Germany in 1912, in metric tons, was:

\begin{tabular}{|c|c|}
\hline & Tons. \\
\hline Coal & $174,875,000$ \\
\hline Lignite (brown coal). & $80,935,000$ \\
\hline Iron ore & $27,200,000$ \\
\hline Zinc ore & 644,000 \\
\hline Lead ore & 143,000 \\
\hline Copper & 974,000 \\
\hline Rock salt & $1,296,000$ \\
\hline Potash & $11,161,000$ \\
\hline Other prod & 582,000 \\
\hline
\end{tabular}

Total value, $\$ 564,000,000$

Here are all the raw materials for guns, armor, and explosives with the exception of cellulose; possibly there would be a shortage in the lead supply if the war lasted indefinitely. The large imports of copper, which last year reached the value of $351,000,000$ marks, might suggest that the cutting off of this outside supply would affect war equipment in some way. If we assume that the imported copper cost 13 cents a pound, the imports amounted to about $640,000,000$ pounds, or somewhat less than one third of the domestic production. The unlikelihood of the suspension of copper imports affecting the supply of war material appears when we find that Germany's exports of copper wire last year amounted to a billion and a third of marks. This is four times the value of the copper imported, and strongly suggests that all the copper imported was brought in for manufacture and subsequent export. It is interesting to note that copper wire represented the highest value of any single article or class of articles exported.

Government and Private Revenues Cut.

The cessation of imports, if it continues long, will cut off a government income from customs duties which amounted in 1911 to $\$ 212,000,000$, and would be more than that this year. The greater part of the imperial income, or at least half of it, is derived from other sources, such as various excise taxes and the income of the imperial railways in Alsace and Lorraine. The cost of the recent expansion in the size of the army has been met by levying special taxes on the German States and on the property holdings and incomes of individuals. A prolonged cessation of commerce will cut off a considerable total of private and banking income through the interruption, or loss, of interest on foreign loans and investments, and this loss will lessen the taxpaying capacity of the people

A larger loss in taxable resources will come from a prolonged cessation of the industries which depend on the export trade. Germany imports all her raw cotton and silk and a considerable part of her wool for manufacture. The early cessation of the textile industries is therefore inevitable, and this will add hundreds of thousands of idle people to the other great numbers thrown out of work by the failure of the export trade.

\section{Calcium Bread} T HE importance of calcium in the human dietary is the desirability of supplying this element, when needed, as an ingredient in bread. The author states that only those adults who use milk and vegetables in abundance secure a sufficient amount of calcium, while those who eat much meat and get their carbohydrates in the form of bread, potatoes, and beer do not. The amount of calcium in the diet appears to be related to certain pathological conditions, such as arteriosclerosis. It is proposed to use in bread-making calcium chlorid and a commercial preparation called "calcifarin," made from rye flour and calcium chlorid. The author thinks it more practical to add calcium to fine flour than to attempt to persuade the public to adopt whole-grain bread. 